\title{
Przeobrażenia gospodarcze w Polsce $w$ latach 1989-2016
}

$\mathrm{P}$ RZEŁOM 1989 R. BYŁ WYNIKIEM ODDOLNEJ DZIAŁALNOŚCI społeczeństwa polskiego. Gdyby patrzeć z perspektywy całej ósmej dekady XX wieku, nastąpił on w okresie najpotężniejszego rozkwitu ruchu solidarnościowego, delegitymizując i w efekcie obalając stary system. Początkowe próby zdefiniowania zachodzących zmian oscylowały wokół takich pojęć, jak: przełom, reformy i rewolucja. Wprowadzenie do obiegu terminologii rewolucyjnej sygnalizowało zamiar przeprowadzenia kompleksowych zmian i całkowite odcięcie się od poprzedniego systemu, a samo wyniesienie jej na sztandary miało na celu wzmocnienie i zradykalizowanie oddolnej mobilizacji społecznej. W definicyjnym opisie terminologii „rewolucja” istotną jest przesłanka, że oto mamy do czynienia nie ze zjawiskiem o cechach zmiany stopniowej, ewolucyjnej, lecz szybkiej i dogłębnej, radykalnie zmieniającej spetryfikowany układ gospodarczo-polityczny, opartej o cenzus czasowy i zawierającej własną logikę, jak i dynamikę. Rewolucyjny charakter głoszonych przekształceń przeprowadzony miał zostać pokojowo, na drodze bezkrwawych, chociaż dynamicznych zmian ewolucyjnych.

Zmiany zachodzące w systemie politycznym wywracały całkowicie dawny, załamujący się porządek i miały na celu całkowite odcięcie od jakiegokolwiek podobieństwa z epoką PRL. Najbardziej zauważalne przemiany dokonywały się natomiast w społeczeństwie, które to zostało wprowadzone w nową, nieznaną i niedoświadczoną przez nie wcześniej rzeczywistość. Ponieważ beneficjentami i benefaktorami zmian byli sami ludzie, stąd też proces przechodzenia na nowoczesne, kapitalistyczne i demokratyczne społeczeństwo został oparty na stopniowych przekształceniach, mimo złożoności pojęcia transformacji i całego systemu społecznego. Przemiana ta w literaturze przedmiotu została określona jako zmiana na najgłębszym poziomie życia społecznego.

Transformacji poddana została również gospodarka, a jej kierunek został wyznaczony przez wolny rynek. Ponieważ rozpoczęte w tej 
dziedzinie przemiany były naprawdę trudne i wymagające, wspierali je przedstawiciele nauk społecznych i ekonomicznych, którzy aktywnie uczestniczyli w budowaniu i normowaniu nowych reguł. Wskazywali oni także kierunki koniecznych modyfikacji w systemie gospodarczym mających ułatwić przejście do „nowego” ładu gospodarczo-społecznego. Jednocześnie tworzący grupy eksperckie na bieżąco poddawali analizie już uruchomione reformy gospodarcze, czuwając nad ich przebiegiem i skutkami, stąd też tak ważna okazała się ich wzmożona aktywność we wstępnym etapie aplikacji projektów modernizujących „nową gospodarkę”. W powszechnej świadomości odnowie uległ proces budowy społeczeństwa obywatelskiego, aktywnie wspierającego zachodzące zmiany, inspirującego i nadającego tempo i kierunek przeprowadzanym reformom. Towarzyszyło temu przekonanie, że zainicjowane reformy były konieczne i oparte na racjonalnych przesłankach, a z kolei zaistniałe doraźne błędy we wdrażaniu nowych rozwiązań postrzegane były skądinąd - w większości przypadków -tylko jako nieprzewidziany skutek implementacji nowych, nieznanych wcześniej reguł. Dodatkowo znaczący wpływ na pojawiające się trudności wywierał niski niekiedy poziom kompetencji merytorycznych części klasy politycznej, jak również zachowawcza postawa niektórych grup społeczeństwa (obawiających się utraty rozbudowanych przywilejów zawodowych) wobec zachodzących przemian. Dopiero po upływie dłuższej perspektywy czasowej dostrzeżono (jak wynika z przeprowadzonych badań Eurobarometru), że za owym stanowczym oporem społecznym stało, między innymi, silne przedkładanie w świadomości obywateli Europy Środkowo-Wschodniej idei „dobra ludzi”, przypisywanej gospodarce socjalistycznej, nad ideę wolnorynkową, identyfikowaną z prymatem „zysku” (CBOS, 2014).

Celem pracy jest rozpoznanie i zanalizowanie zachodzących w Polsce po 1989 r. procesów gospodarczych, określenie kierunków i typów tych przemian oraz ich uwarunkowań strukturalnych i społecznych. Omówienie tak sprecyzowanego zadania wymaga wielowymiarowego ukazania zjawisk wzrostowych i stagnacyjnych w oparciu o dane ekonomiczne zawarte w dalszej części artykułu. Celem poznawczym artykułu jest weryfikacja podejmowanych w opisywanym okresie działań leżących u podstaw procesów transformacji gospodarczo-społecznej w Polsce z uwzględnieniem źródeł napięć towarzyszących zachodzącym przeobrażeniom, skutkujących ambiwalentną oceną społeczną i polityczną. 
Zakres czasowy pracy obejmuje lata 1990-2016, czyli okres transformacji systemu politycznego i gospodarczego Polski. Ograniczone ramy artykułu wymagają skoncentrowania uwagi na interpretacji gospodarki jako najistotniejszego obszaru redefiniującego tempo, zakres i głębię przeobrażeń. Publikacja ma na celu uzyskania odpowiedzi na pytanie: w jakim zakresie i stopniu przeobrażenia gospodarcze po 1989 roku spełniły oczekiwania społeczne i czy doprowadziły do rozwoju cywilizacyjnego Polski. Teza artykułu sprowadza się do stwierdzenia, że pomimo niepowodzeń w pierwszym etapie transformacji ustrojowej i negatywnego odbioru społecznego skutków ubocznych przeprowadzonych reform, pozycja gospodarcza Polski, mierzona stabilnym wzrostem PKB, poziomem efektywności i zmniejszaniem dystansu wobec gospodarek krajów Europy Zachodniej, uległa fundamentalnej poprawie w okresie 1989-2016.

\section{POCZĄTKI TRANSFORMACJI}

Transformacja systemu eKONOMicZno-SPOŁECZNego w Polsce I KRAJACH bloku wschodniego rozpoczęła się z chwilą zderzenia systemu ekonomicznego opartego na centralnym zarządzaniu i własności państwowej z systemem opartym na prywatnej własności, indywidualnej przedsiębiorczości, rynkowej konkurencji, koordynacyjnej roli cen i regulacyjnej roli państwa (Gomułka, 2014, s. 7). System rynkowy okazał się najbardziej przekonującym systemem gospodarczym, bo efektywnie przeciwstawiającym się logice permanentnych niedoborów systemu nakazowo-rozdzielczego, któremu poprzez i w efekcie wyborów parlamentarnych 1989 r. zaufała największa część społeczeństwa i przedstawicieli elit rządzących.

Wyzwaniem dla Polski w 1989 r. było ustabilizowanie sfery makroekonomicznej przy równoczesnym: schładzaniu hiperinflacji, wprowadzaniu do obiegu krajowego waluty wymienialnej, przywróceniu kontroli nad długiem zagranicznym oraz opracowaniu efektywnego systemu bankowego (liberalizacja cen doprowadziła w $1990 \mathrm{r}$. do hiperinflacji - prawie 600\%, jednak dzięki zwiększonym wpływom budżetowym osiągnięto niewielką nadwyżkę). W kolejnym etapie reformatorzy musieli zmierzyć się z pełną liberalizacją cen ${ }^{1}$, rozwojem handlu zagranicznego, ożywieniem produkcji - tak by wyeliminować

${ }^{1}$ Zadaniem procesu liberalizacji cen było stopniowe przywracanie równowagi na rynkach cząstkowych poprzez powiększenie poziomu produkcji a nie wzrostu cen. 
całkowicie niedobory, kolejki przed sklepami i tym samym poprawić nastroje społeczne.

Polska w chwili wdrażania pakietu stabilizacyjnego ${ }^{2}$, dzięki uruchomionemu procesowi legislacyjnemu, była już poważnie zaangażowana w obszar liberalizacji handlu, tak więc w samym dostosowaniu cen dokonano tylko znikomej korekty. Warto w tym miejscu wszakże dodać, że znacząca część cen została uwolniona już w okresie reform z lat osiemdziesiątych ${ }^{3}$ ubiegłego wieku, jednak ze względu na skostniałą, przestarzałą i mało efektywną gospodarkę oraz brak ustaw prorozwojowych nie był to bodziec do oczekiwanego wzrostu gospodarczego. Stopniowy spadek poziomu kontroli cen w okresie dochodzenia do gospodarki wolnorynkowej ${ }^{4}$ wskazuje tabela 1 (Kołodko, 1991, s. 10).

${ }^{2}$ Program gospodarczy rządu z przełomu 1989-1990 r. przewidywał dwa rodzaje działań. Pierwszy, obejmował stabilizację gospodarki, w tym opanowanie inflacji, drugi zaś przeobrażenie systemu gospodarczego. Głównym założeniem fazy pierwszej było: powstrzymanie wzrostu tempa inflacji i jego redukcję, jak również zredukowanie deficytu budżetowego i umocnienie złotówki. W celu niedopuszczenie do głębszego kryzysu związanego z inflacją należało uruchomić procesy prowadzące do przeciwdziałania monopolistycznym praktykom cenowym, jak i likwidacji struktur monopolistycznych poprzez nowelizację prawa $\mathrm{w}$ zakresie prawa spółdzielczego oraz nowej ustawy antymonopolowej. Kolejne mechanizmy to: uruchomienie aktywnej polityki rezerw towarowych celem interwencji rynkowej, modyfikacja zasad indeksacji płac i wzmocnienie podatkowego mechanizmu przeciwdziałania inflacyjnemu wzrostowi wynagrodzeń, uatrakcyjnienie długookresowych programów oszczędnościowych poprzez regulowanie stopy oprocentowania, zahamowanie nadmiernego popytu inwestycyjnego przez organicznie centralnych inwestycji, zaostrzenie polityki kredytowej w tym kredytowej wobec przedsiębiorstw i na koniec rozpoczęcie sprzedaży niektórych składników mienia państwowego (Program Gospodarczy, 1989).

${ }^{3}$ Proces ten wprowadzony został w 1982 r. Ustawą o cenach z dnia 26 lutego 1982 roku, Dz. U. 1982, nr 7, na mocy której wprowadzono trzy kategorie cen uwzględniające różny stopień interwencji państwa w ich kształtowanie: ceny urzędowe, ceny regulowane oraz ceny umowne. Zmonopolizowana i niskoefektywna struktura produkcji sprawiła, że każda podwyżka cen żądana przez producentów/dostawców akceptowana była przez odbiorców/nabywców. W efekcie poziom cen nie odegrał roli „katalizatora” ograniczającego nadmierny popyt. Zmonopolizowana struktura gospodarki w warunkach uwolnienia cen sprzyjała rozwojowi zjawiska inflacyjnego.

${ }_{4}^{4}$ Wprowadzenie ograniczenia stosowania instrumentów hamujących wzrost cen umownych poprzez zarządzenie Ministra Finansów nr 75 z 9 grudnia 1989 r., które to wprowadziło uchylające zarządzenie w sprawie wprowadzenia maksymalnych wskaźników wzrostu cen umownych niektórych grup asortymentowych. Zniesiony zarządzeniem Ministra Finansów obowiązek stosowania maksymalnych wskaźników wzrostu cen umownych dla wielu dóbr konsumpcyjnych i produkcyjnych przesuwa towary i usługi konsumpcyjne oraz wyroby zaopatrzeniowe do grupy podlegającej obowiązkowi informowania izb skarbowych o podwyższeniu cen, co pokazuje tabela 1 . W lipcu 1994 r. maksymalny wskaźnik w towarach i usługach konsumpcyjnych wynosił 
Tabela 1. Struktura cen w Polsce w 1989 roku

\begin{tabular}{|c|c|c|}
\hline Kategoria & lipiec & grudzień \\
\hline \multicolumn{3}{|c|}{ Udziat cen umownych $w$ sprzedaży ogółem $w \%$} \\
\hline towary i usługi konsumpcyjne, w tym: & 71 & 86 \\
\hline żywność & 58 & 93 \\
\hline ceny skupu produktów rolnych & 30 & 41 \\
\hline wyroby zaopatrzeniowe & 86 & 89 \\
\hline surowce i materiały & 89 & 89 \\
\hline \multicolumn{3}{|c|}{$\begin{array}{c}\text { Udziat cen z maksymalnym wskaźnikiem wzrostu i obowiąkiem informowanic } \\
\text { o zamiarze podwyżki } w \%\end{array}$} \\
\hline \multicolumn{3}{|c|}{ Maksymalne wskaźniki } \\
\hline towary i usługi konsumpcyjne & 12.4 & 6.6 \\
\hline wyroby zaopatrzeniowe & 24.7 & 21 \\
\hline obowiązek informowania & 23.6 & 21.4 \\
\hline towary i usługi konsumpcyjne & 4.6 & 5.5 \\
\hline \multicolumn{3}{|l|}{ wyroby zaopatrzeniowe } \\
\hline \multicolumn{3}{|c|}{ Udziat cen catkowicie wolnych $w$ wartości sprzedaży $w \%$} \\
\hline towary i usługi konsumpcyjne & 35.0 & 58.0 \\
\hline wyroby zaopatrzeniowe & 56.7 & 56.5 \\
\hline
\end{tabular}

(Źródło: Kołodko, 1991, s. 10).

12,4\% , a po wprowadzeniu zarządzenia Ministra Finansów jego udział spadł do poziomu $6,6 \%$. Dodatkowo należy dodać, że zarządzenie wyeliminowało kategorię ceny regulowanej na rzecz zwiększenia udziału cen umownych i zmniejszenia udziału cen urzędowych. 
Kolejnym, kluczowym wydarzeniem w nowym systemie ekonomicznym było wprowadzenie indeksacji płac poprzez związanie dopuszczalnego wzrostu funduszu płac w przedsiębiorstwie ze stopą inflacji przy pomocy ustalonych współczynników5

$\mathrm{Z}$ czasem zespół reformatorski musiał się także zmierzyć z rekonstrukcją struktury gospodarki w celu przywrócenia jej zdolności rozwojowych. W ocenie ekonomisty, tranzytologa, profesora Henryka Chołaja, na tamtym etapie upatrywać należało konieczność otwarcia polskiej gospodarki na rynki zagraniczne i oparcia jej na budowie rynku kapitałowego oraz rynku pracy, który miał przyczynić się w dłuższej perspektywie do stopniowego zatarcia luk cywilizacyjnych i ekonomicznych, jakie powstały między Polską a Europą Zachodnią w okresie głębokiego socjalizmu.

\section{REALIZACJA TRANSFORMACJI}

Etapy stabilizacyjne realizowane w Polsce należy rozpatrywać w dużo szerszej perspektywie złożonego procesu przechodzenia z gospodarki centralnie planowanej do gospodarki rynkowej. Transformacja w pewnej mierze wymusiła destabilizację w funkcjonowaniu gospodarki, co wynikało z faktu, że przechodzenie do nowej gospodarki wymagało takich posunięć polityki, jak: liberalizacja cenowa, ograniczenia dotacji, dewaluacja czy znaczna podwyżka stóp procentowych. Polski program stabilizacji otrzymał pozytywną ocenę Międzynarodowego Funduszu Walutowego, jak również został poparty przez społeczeństwo polskie, co w dużej mierze było również efektem zachodzących przeobrażeń politycznych, prowadzących w kierunku demokratyzacji. Niestety, deklarowane cele programowe w początkowym okresie transformacji nie zostały osiągnięte ${ }^{6}$, a koszty znacząco przekroczyły założenia.

${ }_{5}^{5} \mathrm{~W}$ pierwszej połowie 1990 r. współczynniki wyniosły odpowiednio: o,3; o,2; 0,2; 02; o,6 i o,6. Jedynie w lipcu współczynnik został ustalony na poziomie 1,o. Od sierpnia powrócił on do poziomu o,6. Indeksacja płac działała na zasadzie: im wyższa skala spadku płac realnych, tym wyższa stopa inflacji.

${ }^{6}$ Płace realne obniżyły się aż o blisko 30\%, a na jeszcze głębszą recesję finansową narażone zostały salda pieniężne sektora gospodarstw domowych. Poniesione straty były trudne do wyjaśnienia przez rząd, a tym bardziej do zaakceptowania przez społeczeństwo - nawet wówczas, gdyby jeden z podstawowych celów, tj. redukcja stopy inflacji do 1-1,5\% średnio miesięcznie, czyli 13-20\% rocznie, został osiągnięty. Skali inflacji pod koniec roku 1990 i początku 1991, kiedy uległa ona jeszcze większemu nasileniu, nie można porównywać ze wspomnianą quasi - hiperinflacją, a to właśnie ze względu na jej zaindukowany charakter. Tym bardziej niewłaściwym jest porównywanie inflacji z dowolnie wybranych miesięcy z jej najwyższym - całkowicie przecież zaindukowanym - rekordowo wysokim poziomem w styczniu 1990 r. (aż 79,6\% miesięcznie). 
Obrane przez rząd Tadeusza Mazowieckiego założenie w pakiecie stabilizacyjnym, o szybkim wzroście podaży przez przedsiębiorstwa, okazało się nad wyraz optymistyczne. Twórcy pakietu stabilizacyjnego bezkrytycznie przyjęli, że produkcja ożywi się bez ingerencji i pomocy polityki gospodarczej. Niska elastyczność podaży przedsiębiorstw i redukcja popytu wewnętrznego wywołała nieprzewidziany wzrost cen, co w efekcie spowodowało spadek produkcji i wzrost bezrobocia. Podjęte działania interwencjonizmu zostały wprowadzone z dużym opóźnieniem. Dodatkowo zastosowane instrumenty polityki pieniężnej i podatkowej zadziały odwrotnie niż w prawidłowo ukształtowanej gospodarce rynkowej, co pokazuje stopa inflacji oraz założenia i rezultaty dochodu narodowego (zob. tabela 2) (Rolski, 2013, s. 90), a w drugim programie MFW przyjęto dla ostatnich miesięcy $1990 \mathrm{r}$. w październiku 1,5\%, listopadzie 1,0\%, grudniu 2,0\%. Rzeczywista stopa inflacji w ujęciu rocznym wyniosła 90\% (5,5\% miesięcznie).

Tabela 2. Polski program stabilizacyjny: założenia i rezultaty

\begin{tabular}{|c|c|c|}
\hline Wyszczególnienie & Założenia & Rezultaty \\
\hline Stopa inflacji (CPI) w \% & 20,0 & $90,0^{\mathrm{a}}$ \\
\hline Produkcja przemysłu uspołecznionego & $-5,0$ & $-25,0$ \\
\hline Dochód narodowy & $-3,0$ & $-19,0^{\mathrm{b}}$ \\
\hline Bezrobocie & 2,0 & 6,1 \\
\hline Bilans handlowy & & $+2,2$ \\
\hline w mld USD & $-0,8$ & $+6,6$ \\
\hline w mld Rb & $+0,5$ & \\
\hline
\end{tabular}

Źródło: (Kołodko, 1991, s. 13).

Warto zaznaczyć, że stopa inflacji ulegała zmniejszeniu w czwartym kwartale 1989 r., obniżając się z około $55 \%$ do $23 \%$ w październiku i 17\% w listopadzie i grudniu. „Jeśli zatem uprawomocniona jest teza o indukowanym charakterze polskiej quasi-hiperinflacji, to punktem odniesienia dla 100-procentowej inflacji, do której doszło w wyniku realizacji pakietu stabilizacyjnego i towarzyszących mu procesów (w tym także w ostatnim okresie niesprzyjających uwarunkowań zewnętrznych), jest 160-procentowa inflacja z pierwszej połowy 1989 r. Z takiej dopiero perspektywy widać, jak mizerne efekty przyniósł odnośnie do stabilizacji inflacji tzw. polski Big Bang” (Kołodko, 1991, s. 14). 


\section{5-LECIE TRANSFORMACJI GOSPODARCZEJ}

Zauważalne ożywienie w gospodarce polskiej nastąpiło w połowie 1992 r., a od 1994 roku ustabilizowało się i nabrało trwałych podstaw. Czynnikiem potwierdzającym trwałość gospodarki było utrzymanie się wysokiego tempa wzrostu PKB (co ilustruje tabela 3).

Tabela 3. PKB Polski w latach 1992-2014

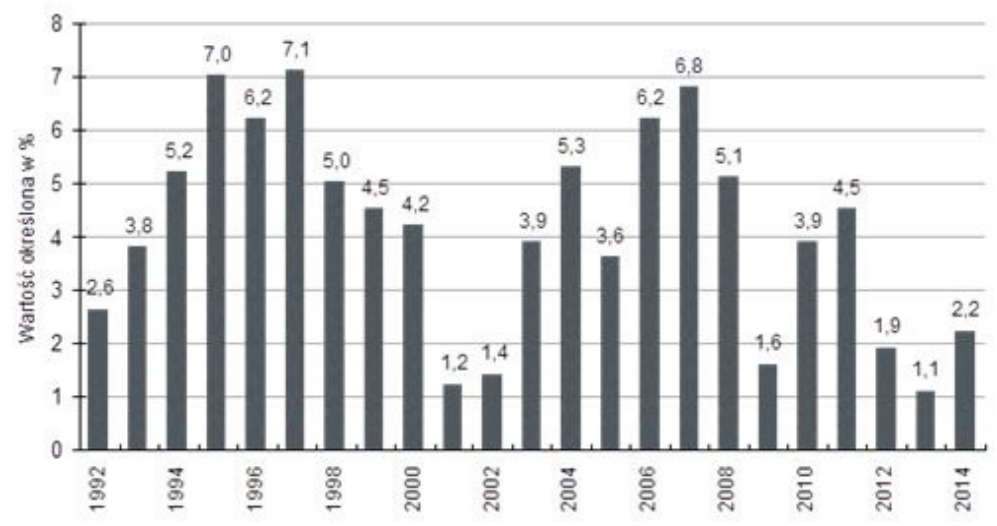

Źródło: opracowanie własne na podstawie (GUS, 2015).

Według danych Conference Board7, PKB Polski w latach 19902014 zwiększył się ponad 135\% i był to największy wzrost ze wszystkich państw regionu. Polska uzyskała najszybszy wzrost gospodarczy w grupie nowych krajów członkowskich Unii Europejskiej (UE13 i przeszło dwukrotnie wyższy niż średnio w krajach tzw. starej Unii (UE15).

${ }^{7}$ Non profit organizacja badawcza dla firm, która przekazuje informacje na temat gospodarki i rynku. Jest szeroko cytowanym medium z obszaru gospodarki, rynku, ładu korporacyjnego. 
Tabela 4. PKB w latach 1990-2014

\begin{tabular}{|c|c|c|c|c|c|c|c|c|}
\hline \multirow{3}{*}{ Kraj } & \multicolumn{5}{|c|}{ Dynamika wzrostu PKB (ceny stałe) } & \multirow{2}{*}{\multicolumn{3}{|c|}{ Poziom PKB w 2014}} \\
\hline & $\begin{array}{l}\text { Srednia } \\
\text { roczna } \\
\text { stopa }\end{array}$ & \multicolumn{4}{|c|}{ Roczna stopa wzrostu w \% } & & & \\
\hline & $1990-2014$ & 2004 & 2012 & 2013 & 2014 & $1989=100$ & $2000=100$ & $2004=100$ \\
\hline Polska & 3,0 & 5,1 & 1,8 & 1,7 & 3,5 & 211 & 164 & 146 \\
\hline Czechy & 1,4 & 4,9 & $-0,8$ & $-0,7$ & 2,5 & 141 & 143 & 125 \\
\hline Słowacja & 2,3 & 5,2 & 1,6 & 1,4 & 2,4 & 177 & 173 & 145 \\
\hline Węgry & 1,1 & 4,8 & $-1,5$ & 1,5 & 3,6 & 133 & 126 & 107 \\
\hline Słowenia & 1,4 & 4,4 & $-2,6$ & $-1,0$ & 2,7 & 141 & 128 & 111 \\
\hline Estonia & 1,6 & 6,5 & 4,7 & 1,6 & 1,5 & 148 & 162 & 126 \\
\hline Litwa & 0,7 & 7,4 & 3,8 & 3,3 & 3,1 & 120 & 179 & 133 \\
\hline Lotwa & 0,5 & 8,9 & 4,8 & 4,2 & 2,5 & 112 & 169 & 126 \\
\hline Bułgaria & 0,5 & 6,6 & 0,5 & 1,1 & 1,7 & 114 & 156 & 127 \\
\hline Rumunia & 0,9 & 8,4 & 0,6 & 3,4 & 2,9 & 124 & 164 & 129 \\
\hline Chorwacja & 0,0 & 4,1 & $-2,2$ & $-0,9$ & $-0,6$ & 99 & 122 & 102 \\
\hline UE 15 & 1,5 & $2,3^{\mathrm{a}}$ & $-0,6^{a}$ & $-0,1^{a}$ & $1,2^{\mathrm{a}}$ & 146 & 116 & 108 \\
\hline
\end{tabular}

a średnia ważona, obliczona na podstawie danych MFW dla danego roku. Średnie nieważone wynoszą w 2004 roku 3,1, 2012 r. - 1,1, 2013 r. - 0,3 i 2014 r. - 1,3.

${ }^{\mathrm{b}}$ Dochód narodowy Polski podzielony. 
Do określenia wskaźników wzrostu, na przykład 1989 = 100, wykorzastano dane EBOR z 1989 roku.

Źródło: opracowanie własne na podstawie: Eurostat (2015) (Weresa, 2015, s. 20).

Na podstawie danych z tabeli 5 , cel postawiony przez reformatorów w trzecim etapie ${ }^{8}$ stabilizacji gospodarczej 1989 r. został w dużej mierze zrealizowany. Wysokie tempo wzrostu niemal we wszystkich składnikach popytu finalnego oraz PKB istotnie zmniejszyło dystans do państw regionu oraz gospodarek bardziej rozwiniętych. Należy podkreślić, że w 1990 r. mieszkańcy większej części naszego regionu mieli wyższe dochody od Polaków (Czesi o 96\%, Węgrzy o 70\%). Od tego czasu (jako kraj) wyprzedziliśmy Węgry i znacznie zmniejszyliśmy dystans w stosunku do Czech. Zasadniczy wpływ na zmianę pozycji rozwojowej polskiej gospodarki miało: szybkie tempo wzrostu

\footnotetext{
${ }^{8}$ Pierwszy etap, założony przez reformatorów, dotyczył wprowadzenia w życie programu z października 1989 r., który zakładał dokonanie gruntownych przekształceń własnościowych, wdrożenia aktywnej polityki antymonopolowej i likwidacji struktur monopolowych, liberalizacji cen, otwarcia gospodarki na świat, uruchomienia rynku kapitałowego oraz dopuszczenia inwestycji zagranicznych. Drugi etap oparty był na zmianach strukturalnych, które miały doprowadzić do powstania i umacniania procesów wzrostowych (PKB na przykład w 1993 r. zwiększył się o 6,5\% w porównaniu do 1992 r.) ograniczające tempo spadku zatrudnienia. Trzeci etap zakładał zmiany jakościowe oraz ilościowe w gospodarce, oparte na: zwiększeniu popytu inwestycyjnego i eksportu, oddłużenie przedsiębiorstw, proinwestycyjnym rozwiązaniu systemu podatkowego i kredytowego, zwolnieniu tempa inflacji, zwiększeniu udziału kapitału zagranicznego (Balcerowicz, 1997, s. 374 - 384).
} 


\section{gospodarczego, zmiany demograficzne w $\mathrm{UE}^{9} \mathrm{i}$ wzrost kursów walut w poszczególnych krajach ${ }^{10}$. \\ Do najważniejszych osiągnięć polskiej gospodarki w minionym ćwierćwieczu należy zaliczyćc ${ }^{11}$ :}

${ }^{9}$ Wielu badaczy oraz instytucji międzynarodowych używa jako miernika rozwoju gospodarczego dochodu narodowego lub produktu krajowego brutto oznaczonym skrótem PKB albo GDP (Gross Domestic Produkt). Stosowanie tych mierników opiera się na założeniu, że wartość wygenerowanego w gospodarce dochodu/produktu świadczy o potencjale ekonomicznym gospodarki (Bąkiewicz, Żuławska, 2010, s. 91). Zaznaczyć jednak należy, iż taka miara obrazuje zmiany ilościowe w gospodarce, a zatem jest wyznacznikiem wzrostu. Aby jednak mówić o rozwoju gospodarczym, należy oprócz zmian ilościowych analizować także zmiany jakościowe w strukturze społecznoekonomicznej kraju (Wozniak, 2008, s. 20). Czynnikiem mającym duży wpływ na kształtowanie się PKB jest poziom demografii. W latach 9o. ubiegłego wieku sytuacja demograficzna Polski była korzystniejsza niż w wielu krajach europejskich, a proces starzenia się społeczeństwa polskiego był mniej zaawansowany niż w krajach Unii Europejskiej (Hryniewicz, 1999, s. 27). W Polsce udział ludności w wieku poprodukcyjnym w całości populacji w $1995 \mathrm{r}$. był na stosunkowo niskim poziomie i wynosił 13,77\%; natomiast na Węgrzech szacował się na 19,4\%, na Ukrainie - 18,4\%, w Bułgarii - 21,3\% , a w Czechach 18\% (Hausner, 1998, s. 55). W latach 1990 - 1998 następował powolny proces starzenia się polskiego społeczeństwa, wskaźnik starości i współczynnik zależności demograficznej wykazywały tendencję rosnącą, a rosnący wskaźnik przewidywanej długości życia w 1995 r. wyniósł 76,4 lat dla kobiet 67,6 dla mężczyzn (Rączaszek, 2012, s. 37).

10 Kurs walutowy jest jednym z najistotniejszych czynników determinujących dynamikę i strukturę obrotów handlowych. Zależność między kursem walutowym a obrotami handlowymi jest dwustronna. $Z$ jednej strony kurs walutowy wpływa na kształt importu i eksportu z danego kraju, a z drugiej strony zmiany poziomu wymiany gospodarczej i struktury bilansu handlowego oddziałują na kurs walutowy. W 1989 r. eksport był szacowany na około $14 \mathrm{mld}$ dol. (9 mld dol. stanowił eksport na rynki światowe, a około 5 mld dol. do krajów komunistycznych). W kolejnych 2 latach eksport do większości krajów komunistycznych zakończył się wraz z rozpadem Rady Wzajemnej Pomocy Gospodarczej (RWPG). W 2000 r. eksport wzrósł do poziomu 32 mld dol. Przełom w poziomie eksportu nastąpił w okresie członkostwa Polski w Unii Europejskiej. W 2013 r. Polska sprzedała za granicę towary warte 203 mld dol. i uplasowała się na 26. miejscu w rankingu największych eksporterów świata. Generalnie rzecz ujmując, zmniejszenie realnego kursu wymiennego złotego w stosunku do euro oznacza realną aprecjację złotego i co jest bezpośrednim przełożeniem na poziom obrotu uzyskany z eksportu. Sprzedaż polskich towarów na koniec 2015 r. sięgną prawie 176 mld euro. Wartość eksportu towaru i usług w relacji do PKB wzrosła z 27,2\% w $2000 \mathrm{r}$. aż do 46,8\% w 2014 r. (http://www.obserwatorfinansowy.pl/tematyka/makroekonomia/ eksport-jest-i-pozostanie-polskim-priorytetem/2)

${ }^{11} \mathrm{~W}$ dalszym przebiegu transformacji rząd Waldemara Pawlaka w programie „Strategia dla Polski" nie przewidywał wprowadzania rewolucyjnych ustaw, ale prowadzenie umiejętnej, prorozwojowej gospodarki w ramach istniejącego prawodawstwa gospodarczego. Sprawą kluczową dla nowej polityki gospodarczej miały być, między innymi, obniżenie społecznych kosztów reform, silna orientacja na wzrost gospodarczy, akty- 
- rozwój sektora prywatnego - szacuje się, że w 1989 r.powstało blisko 400 tysięcy nowych przedsiębiorstw. Wysoki wzrost prywatnych przedsiębiorstw tłumaczy szybki wzrost udziału sektora prywatnego w PKB, uwzględniając powolną prywatyzację polskich przedsiębiorstw państwowych (Gomułka, 2014 s. 13);

- rozważna polityka monetarna - złoty stał się w pełni wymienialną walutą, dzięki odpowiedniej polityce finansowej, a Polska uniknęła kryzysu walutowego. Dzięki ograniczeniu

wna polityka państwa w restrukturyzacji makro- i mikroekonomicznej, równoprawne traktowanie wszystkich sektorów własności. Natomiast Plan Hausnera (rząd Leszka Millera) w swoich założeniach oparty był na trzech zasadniczych filarach: działaniach w zakresie administracji i gospodarki, pozyskiwaniu dochodów budżetowych oraz na zmianach w zakresie wydatków socjalnych. W ramach pierwszego zakładano, między innymi, ograniczenie wydatków administracyjnych, porządkowanie funduszy celowych oraz agencji skarbu państwa, ograniczenie wydatków budżetowych o niskiej efektywności (na przykład zalesiania), konsolidację niektórych jednostek administracji rządowej. Zwiększenie dochodów budżetu miało dać, miedzy innymi, zlikwidowanie środków specjalnych w ministerstwach, porządkowanie wydatków na obronność, ograniczenie pomocy publicznej, restrukturyzacja PKP i górnictwa węgla kamiennego. Zmiany w zakresie wydatków socjalnych miały dotyczyć głównie systemu emerytalnego i zasad przyznawania wcześniejszych emerytur, systemu rent z tytułu niezdolności do pracy i aktywizacji zawodowej i społecznej osób niepełnosprawnych.

Program reform finansów publicznych Zyty Gilowskiej (rząd Jarosława Kaczyńskiego) zakładał kontynuację reformy organizacji sektora finansów publicznych poprzez maksymalne skupienie publicznych środków w systemie budżetowym i konsolidację sektora finansów publicznych, a przez to uczynienie ich bardziej przejrzystymi i podatnymi na kontrolę. Oszczędności z tytułu wprowadzonych zmian miały sięgnąć 1 proc. PKB, czyli ok. 10 mld zł.

Natomiast raport „Polska 2030. Wyzwania Rozwojowe” opracowany pod przewodnictwem Michała Boniego miał stanowić fundament długookresowej strategii rozwoju dla Polski. Dokument był kompleksowym narzędziem wyznaczającym kierunek rozwoju kraju. Obok długookresowej istnieje też strategia średniookresowa - do roku 2020 i dziewięć zintegrowanych strategii sektorowych - także do roku 2020. Są konieczne, między innymi, do sprawnego wykorzystania funduszy unijnych w nowej perspektywie budżetowej (2014-2020). Jedną z takich strategii jest przygotowana w MAiC strategia „Sprawne Państwo 2020”. Skupia się ona na rodzaju metod, jakie miałyby doprowadzić do zwiększenia skuteczności i efektywności państwa otwartego na współpracę z obywatelami. Zakłada ona, że Polska powinna realizować model państwa optimum (a więc taki, w którym państwo nie jest ani przeregulowane - jak państwo maximum, ani wycofane jak państwo minimum). Sposobem na tworzenie takiego państwa jest przejrzystość (na przykład prawa, procedur i procesu decyzyjnego); efektywność (na przykład sprawna komunikacja i wymianą dokumentów); szeroka współpraca przy realizacji zadań i rozwiązywaniu problemów między różnymi podmiotami, w tym między rządem a samorządem terytorialnym; zaangażowanie i uczestnictwo obywateli w procesie podejmowania decyzji przez administrację publiczną, w tworzeniu lepszego prawa oraz w dążeniu do wysokich standardów świadczonych usług (MAiC, 2013). 
ekspansji kredytowej banków komercyjnych, Polska uniknęła wahań cyklicznych i baniek finansowych (Łaszek, 2015, s. 31);

wzrost udziału bezpośrednich inwestycji zagranicznych - sprzyjało to lepszemu wykorzystaniu kapitału i wyższej produktywności pracy;

- otwarcie na świat - dzięki sprawnie przeprowadzonej liberalizacji handlu zagranicznego wymiana międzynarodowa w ostatnim 25-leciu była wyższa w stosunku do wielu gospodarek o podobnej wielkości rynku wewnętrznego;

- przystąpienie Polski do Unii Europejskiej wymusiło wdrożenie instytucjonalnych i strukturalnych reform wymaganych przez UE. Otrzymaliśmy mechanizmy wpływające bezpośrednio na nasz wzrost gospodarczy, między innymi: napływ bezpośrednich inwestycji zagranicznych, transferów pieniężnych emigrantów, funduszy unijnych, wzrost otwartości rynku oraz napływ nowych technologii;

- $\quad$ wzrost łącznej produktywności czynników produkcji (Total Factor Productivity ${ }^{12}$ ) i, w mniejszym zakresie wzrost, zasobu kapitału od 1995 r. Przesunięcie czynników produkcji, takich jak praca czy kapitał, pomiędzy poszczególne sektory, prowadziło do wzrostu produktywności. Istotne były również w klasycznym rozumieniu zmiany wewnątrz sektorów, takich jak: górnictwo czy przemysł przetwórczy. Według danych Conference Board, w latach 1990-2014 produktywność polskiej gospodarki zwiększyła się o 235\%. Produktywność pracy w przeliczeniu na godzinę wzrosła z kolei z niecałych $30 \%$ w 1990 roku do niecałych 50\% poziomu niemieckiego w 2014 r. Niższą produktywność na godzinę pracy Polacy częściowo kompensują dłuższym czasem pracy.

${ }^{12}$ Źródło wzrostu produktywności może wynikać z zastosowania lepszych technologii, przepływu istniejących czynników produkcji (pracowników i maszyn) z mniej na bardziej wydajnych zastosowań. W praktyce może to być na przykład przepływ ludzi z rolnictwa (sektor o bardzo niskim poziomie produktywności) do przemysłu (sektor o bardzo wysokim poziomie produktywności) lub też przepływ z mniej do bardziej produktywnych firm. 
Tabela 5. Zmienny poziom rozwoju w Polsce i wybranych krajach UE w latach 19892014

\begin{tabular}{|c|c|c|c|c|c|c|c|c|c|}
\hline Kraj & 1989 & 2000 & 2004 & 2006 & 2008 & 2010 & 2012 & 2013 & 2014 \\
\hline Polska & 100 & 100 & 100 & 100 & 100 & 100 & 100 & 100 & 100 \\
\hline Niemcy & 279 & 243 & 237 & 230 & 211 & 192 & 186 & 182 & 179 \\
\hline Francja & 268 & 238 & 224 & 216 & 193 & 174 & 162 & 160 & 155 \\
\hline Włochy & 274 & 243 & 220 & 212 & 193 & 168 & 153 & 148 & 142 \\
\hline $\begin{array}{c}\text { Wielka } \\
\text { Brytania }\end{array}$ & 256 & 248 & 255 & 246 & 207 & 174 & 162 & 163 & 162 \\
\hline Hiszpania & 199 & 200 & 204 & 206 & 185 & 158 & 142 & 140 & 137 \\
\hline Irlandia & 195 & 271 & 292 & 292 & 240 & 208 & 197 & 194 & 197 \\
\hline Portugalia & 159 & 167 & 157 & 160 & 144 & 131 & 115 & 118 & 115 \\
\hline Grecja & 178 & 174 & 194 & 186 & 169 & 140 & 112 & 109 & 106 \\
\hline $\begin{array}{c}\text { Srednia dla } \\
\text { UE15 } \\
\end{array}$ & 262 & 238 & 232 & 226 & 202 & 178 & 166 & 163 & 159 \\
\hline Czechy & 197 & 145 & 161 & 162 & 149 & 131 & 124 & 122 & 121 \\
\hline Węgry & 146 & 112 & 127 & 124 & 115 & 105 & 98 & 99 & 99 \\
\hline Słowacja & 155 & 102 & 116 & 126 & 129 & 118 & 112 & 112 & 111 \\
\hline Słowenia & 194 & 164 & 176 & 172 & 162 & 134 & 124 & 122 & 122 \\
\hline Estonia & 142 & 93 & 112 & 128 & 124 & 102 & 108 & 109 & 107 \\
\hline Litwa & 145 & 81 & 102 & 112 & 115 & 97 & 105 & 109 & 109 \\
\hline Łotwa & 137 & 76 & 98 & 110 & 109 & 85 & 91 & 96 & 95 \\
\hline Bułgaria & 122 & 60 & 69 & 74 & 78 & 69 & 68 & 67 & 66 \\
\hline Rumunia & 89 & 55 & 69 & 76 & 87 & 81 & 80 & 82 & 82 \\
\hline Chorwacja & 133 & 102 & 116 & 116 & 116 & 95 & 92 & 91 & 87 \\
\hline
\end{tabular}

$(\mathrm{PKB}$ na 1 mieszkańca według PSN, Polska $=100)$.

Źródło: opracowanie własne na podstawie: (Eurostat, (2015), (IMF, (2005), (Weresa, 2015, s. 21). 


\section{PRognOZa NA 2015}

TRUDNOŚCI PIERWSZEGO ETAPU TRANSFORMACJI USTROJOWEJ (1989 - 1992), skutkujące gwałtownym wzrostem inflacji, spadkiem poziomu dochodu narodowego i wzrostem bezrobocia, wywołały negatywny rezonans społeczny. Na fali niezadowolenia ugruntowały się przekonania o aspołecznej roli części elit politycznych, co w konsekwencji doprowadziło do braku identyfikacji dużych grup społecznych z przeprowadzonymi reformami gospodarczymi (Balcerowicz, 1997, s. 374 - 384). Pomimo znacznego wzrostu PKB (135\% w latach 1990 - 2014) i osiągnięcia poziomu lidera przemian gospodarczych w Europie Środkowej, społeczeństwo polskie zanegowało wizję kontynuacji dotychczasowej polityki gospodarczej, odrzucając w wyborach parlamentarnych $2015 \mathrm{r}$. ideologię liberalną na rzecz prospołecznej i narodowo-konserwatywnej. Brak spójnej polityki społecznej, rozbudzenie nadmiernych oczekiwań, błędy personalne i populizm części klasy politycznej wzmocniły dotychczasowe poczucie alienacji grup społecznych domagających się zmian i negujących kształt przeprowadzanych reform gospodarczych ${ }^{13}$.

Prognozy wzrostu gospodarczego dla Polski na rok obecny i następny różnią się w zależności od źródła i planu przeprowadzanych reform. Komisja Europejska w swojej prognozie gospodarczej dla Europy, opublikowanej 5 lutego 2015 roku (European Commission, 2015), znacznie podniosła swe poprzednie szacunki dotyczące spodziewanego wzrostu PKB w Polsce w 2016 r. do 3,4\%. Podobne prognozy wzrostu PKB dla Polski na 2016 r. zostały ogłoszone przez: MFW - 3,5\% w 2016 r.; OECD - 3,5\% oraz Bank Światowy (World Bank) - 3,0\%. Przy opracowywaniu ustawy budżetowej na rok 2016 rząd zakładał (Rada Ministrów, 2015), że PKB Polski wyniesie 3,6\%.

Cele Rządu Polski na 2020 rok zostały zawarte w dokumencie zatytułowanym „Plan na rzecz odpowiedzialnego rozwoju Polski”. Plan ten został oparty na pięciu filarach:

1. Pierwszy filar - reindustralizacja - opiera się on na wspieraniu tych gałęzi przemysłu, które cechuje silny rozwój. Wskazano tu na: przemysł medyczny, informatyczny i lotniczy. Sam kształt wsparcia jest na razie niejasny.

2. Drugi filar - Rozwój innowacyjnych firm - ma zawierać tak zwaną „Konstytucję dla biznesu”, czyli spis zasad o charakterze bardziej przewidywalnym, opisujący transparentne warunki do prowa-

${ }^{13}$ Wnioski na podstawie raportu przyczyn niezadowolenia wyborców poszczególnych partii politycznych (Raport Przyczyny, 2015) 
dzenie biznesu zarówno z punktu widzenie elementów skarbowych, jak i regulacyjnych. Została w nim także zawarta Reforma Instytutów Naukowo-Badawczych.

3. Trzeci filar - Kapitał dla rozwoju - jego celem jest rozwój oparty na krajowych funduszach kapitałowych. Oszczędności trzeciofilarowe, oszczędności prywatne, ale też oszczędności publiczne mają stanowić podstawowy element wzmocnienia programu inwestycyjnego, industrializacyjnego.

4. Czwarty filar - Ekspansja zagraniczna - w założeniach ma się ona dokonać, między innymi, za sprawą: utworzenia Pionu Wspierania Eksportu w Polskim Funduszu Rozwoju; reformy dyplomacji ekonomicznej; budowy silnej marki Polska.

5. Piąty filar - Rozwój społeczny i regionalny - niwelowanie różnic i barier terytorialnych ma zagwarantować: pakt dla obszarów wiejskich, skuteczna polityka regionalna oraz edukacja (Ministerstwo Rozwoju, 2016).

\section{Podsumowanie}

GŁÓWNA TEZA ARTYKUŁU SPROWADZA SIĘ DO STWIERDZENIA, ŻE ZAKOŃCZOna sukcesem liberalizacja gospodarki, jej pełna adaptacja w struktury wolnorynkowe, pomimo zróżnicowanego odbioru społecznego i wzmagającego się oporu dużych grup pracowników, dotkniętych kosztami przeobrażeń, jest niezaprzeczalnym osiągnięciem całego społeczeństwa. Powszechna, społeczna akceptacja kierunku reform gospodarczych spowodowała, że priorytetem działań po 1989 r. stały się cele ekonomiczne, co jednak w konsekwencji doprowadziło do zaniedbania i zmarginalizowania celów społecznych. Coraz głośniej więc wybrzmiewają głosy negujące znaczenie reform i ich wpływ na rozwój społeczny, jak i tezy, że oddzielenie w okresie transformacji aspektów ekonomicznych od działań prospołecznych, minimalizujących alienację i poczucie wykluczenia, było „grzechem zaniechania” koncepcji społecznej gospodarki rynkowej będącej podstawowym elementem spójności polityki społecznej z polityką gospodarczą państwa.

Za główną przyczynę problemów społecznych i negacji polityki liberalnej uznać należy niepowodzenia we wdrażaniu koncepcji społecznej gospodarki rynkowej. Model reform, oparty na koncepcji monetarystyczno-liberalnej, będący efektem dostosowania się do programu Międzynarodowego Funduszu Walutowego wymusił odejście od wyraźnie zakreślonej strategii rozwojowej, co bezpośrednio przełożyło się na przesunięcie na drugi plan istotnych zagadnień dla długo- 
falowego rozwoju kraju. Chodzi w szczególności o obszary związane z bezpieczeństwem osobistym obywateli, opieką zdrowotną, oświatą i rozwojem infrastrukturalnym, które przez kolejne rządy były marginalizowane a ich realizacja przesuwana w czasie. Towarzysząca temu zjawisku korupcja i rosnąca stopa bezrobocia były głównymi determinantami rozwarstwienia ekonomicznego w obszarze dochodów społeczeństwa polskiego, co w efekcie skutkowało, i skutkuje po dzień dzisiejszy, licznymi napięciami społecznymi.

Obecne propozycje rządu zawarte w projekcie zatytułowanym „Plan na rzecz odpowiedzialnego rozwoju Polski” w zaprezentowanych ogólnych założeniach, w sposób mało jednoznaczny, przedstawiają zakładaną synergię polityki gospodarczej z polityką społeczną.

Niezbędne jest wypracowanie „złotego środka”, który będzie w stanie pogodzić tak zwany europejski model socjalny, charakteryzujący się respektowaniem zasad solidaryzmu i funkcjonalnej równości, z motywacjami do wzrostu przedsiębiorczości oraz niezbędnej elastyczności działania w dalszej transformacji ekonomicznej kraju.

\section{Bibliografia:}

Arendt H. (1998), O przemocy. Niepostuszeństwo obywatelskie, Wydawnictwo Fundacja Aletheia, Warszawa.

Baka W. (1999), U źródeł wielkiej transformacji, Oficyna Naukowa, Warszawa.

Balcerowicz L. (1997), Socjalizm, kapitalizm, transformacja. Szkice z przetomu epok, Wydawnictwo Naukowe PWN, Warszawa.

Balcerowicz L. (1992), 800 dni: szok kontrolowany , Polska Oficyna Wydawnicza BGW, Warszawa.

Bałtowski M. Miszewski M., (2015), Transformacja gospodarcza $w$ Polsce, Wydawnictwo Naukowe PWN SA, Warszawa.

Barański M. Wiśniewski J., (2014), 25 lat transformacji $w$ krajach Europy Środkowej $i$ Wschodniej, Wydawnictwo Uniwersytetu Śląskiego, Katowice.

Bąkiewicz A. Żuławska U., (2010), Rozwój $w$ dobie globalizacji, PWE, Warszawa.

Błuszkowski J. (2008), Dylematy polskiej transformacji, Dom §wydawniczy Elipsa, Warszawa.

CBOS, (2014), Polacy o gospodarce wolnorynkowej, http://www.cbos.pl/ SPISKOM.POL/2014/K_031_14.PDF 
Chołaj H. (1998), Transformacja systemowa $w$ Polsce. Szkice teoretyczne, UMCS nr 24.

Czerwińska E. (1993), Znaczenie obrotów handlowych z ZSRR dla Polski przed zmianami systemowymi i obecne tendencje, Kancelaria Sejmu Biuro Studiów i Ekspertyz, Warszawa.

Polska 2030. Wyzwania Rozwojowe https://mac.gov.pl/files/wp-content/ uploads/2013/o2/Strategia-DSRK-PL2030-RM.pdf, 26.02.2016.

Filar D. (1993), Ekonomiczno-społeczna transformacja postsocjalistyczna - prawidłowości czy same wyjątki?, [w]: Ekonomia wobec zagadnień transformacji, UW, Warszawa.

Gomułka S. (2014), Transformacja gospodarczo-społeczna Polski 1989-2014 i wspótczesne wyzwania, „NAUKA”, nr 3/2014.

Hryniewicz J. (1999), Wybrane aspekty spoleczne i ekonomiczne reformy ubezpieczeń społecznych, „Gospodarka Narodowa”, nr 3.

Jarosz M., (2005), Polska. Ale jaka?, Oficyna Naukowa, Warszawa.

Kmieciak R., (2000), Polska w XX wiek. Politologiczna charakterystyka dokonań i perspektyw rozwoju, Wydawnictwo Naukowe Instytutu Nauk Politycznych i Dziennikarstwa, Poznań.

Kołodko G. W. (1991), Polityka finansowa stabilizacja transformacja, Instytut Finansów, Warszawa.

Kołodko G. W. (1990), Polska hiperinflacja i stabilizacja, „Ekonomista” nr 6, Warszawa.

Listwan T. (2005), Dylematy transformacji systemowej $w$ Polsce, Wydawnictwo Forum Naukowe, Poznań - Wrocław.

Łaszek A. (2015), Następne 25 lat. Jakie reformy musimy przeprowadzić, by dogonić Zachód?, Fundacja Forum Obywatelskiego Rozwoju, Warszawa.

Orłowski W., M. (2010), W pogoni za straconym czasem. Wzrost gospodar$c z y$ Europie środkow-wschodniej 1950-2030, Polskie Wydawnictwo Ekonomiczne, Warszawa.

Plan na rzecz odpowiedzialnego rozwoju, (2016), https://www.premier.gov. $\mathrm{pl} /$ wydarzenia/decyzje-rzadu/plan-na-rzecz-odpowiedzialnego-rozwoju. html, 26.02.2016.

Płonka-Syroki B., Szlagowska A., (2010), Globalizacja i transformacje ustrojowe $w$ świecie nowoczesnym i ponowoczesnym. Wybrane problemy. Oficyna Wydawnicza Arboretum, Warszawa.

Program Gospodarczy. Główne założenia i kierunki, (1989), http://c355.republika.pl/Program1989.pdf, 26.02.2016 r.

Raport przyczyny niezadowolenia wyborców poszczególnych partii politycznych, (2015), 
http://arc.com.pl/image/www/Raport_Przyczyny_niezadowolenia_wyborcow_ARC_Rynek_i_Opinia.pdf, 26.02.2016 r.

Rączaszek A. (2012), Demograficzne uwarunkowania rozwoju gospodarczego, Wydawnictwo Uniwersytetu Ekonomicznego w Katowicach.

Rolski M. (2013), Krytyka Planu Balcerowicza w ujęciu Grzegorza Kołodki oraz Tadeusza Kowalika, „Studia Ekonomiczne. Zeszyty Naukowe Uniwersytetu Ekonomicznego w Katowicach" nr 130, Katowice.

Stiglitz J. E, (2004), Globalizacja, Wydawnictwo Naukowe PWN, Warszawa.

Sztompka P. (1999), Impon Dera Bilia Wielkiej Zmiany, Mentalność, wartości i więzi społeczne czasów transformacji, Wydawnictwo Naukowe PWN, Warszawa-Kraków.

Tomaszewski W. Chełminiak M. (2011), 20 lat transformacji $w$ Polsce, Instytut Nauk Politycznych Uniwersytet Warmińsko-Mazurski w Olsztynie, Olsztyn.

Welfe A. (2000), Gospodarka Polski w okresie transformacji, Polskie Wydawnictwo Ekonomiczne, Warszawa.

Weresa M., A. (2015), Polska Raport o konkurencyjności 2015. Innowacje a pozycja konkurencyjna polskiej gospodarki w latach 2007-2014, Oficyna Wydawnicza Szkoła Główna Handlowa w Warszawie, Warszawa.

Wilkin J. (1995), Ekonomia polityczna kapitalizmu, Wydawnictwo Naukowe PWN, Warszawa.

Woźniak M.G, (2008), Wzrost gospodarczy. Podstawy teoretyczne, Wydawnictwo Uniwersytetu Ekonomicznego w Krakowie, Kraków.

\section{SUMMARY}

The article has two purposes, to describe situations of transition. One is to identify the distinctive features of the Polish transformation which may explain why the initial, transformational recession implementation of the economic system. The other objective is to discuss the reforms and policies needed for Poland to continue the process of catching up with the most advanced countries transformation has given citizen. what changes occur for the better. What led to the change and what were the results. a summary of the transformation after 25 years. show a deep analysis of the situation in the EU, plans for the future growth and economic plans of the new government. 


\section{Nota O AUTORZE}

Dariusz Leszczyński [dariusz.leszczynski.uam@gmail.com] - student IV roku studiów doktoranckich na Wydziale Nauk Politycznych i Dziennikarstwa Uniwersytetu im. Adama Mickiewicza w Poznaniu. 